conjunctiva in any of the cases. The right preauricular gland was enlarged and tender. On admission, the temperature was normal, but rose to $100^{\circ}$ the following day, then fell to normal and did not rise again. He was treated by hot fomentations. On the third day-seventh day of disease-the preauricular gland was punctured with the usual precautions to avoid organismal contaminations. A needle on a syringe containing about half a cubic centimetre of broth was introduced, and the point of the needle moved about in the gland, slight positive and negative pressure being alternately exerted. The gland pulp thus obtained in broth was planted on blood agar, serum agar and Soparkar's medium (for composition see Indian Jl. of Med. Research, Vol. VI, page 418 ), and yielded in all a pure culture of the diplobacillus of Morax and Axenfeld.

This does not necessarily indicate that the other two cases were due to the same organism, and the reader may well wonder why the other cases were not investigated in the same way, or, why the preauricular gland was punctured rather than the lacrymal gland. The reason is that we did not take the aetiological problem seriously till the third case was well advanced. It occurred to us then, that there was a possibility of an epidemic of acute dacryoadenitis and by this time the preauricular gland was easier to deal with. It may be objected that even in the one case investigated it is not proven that the organism isolated from the preauricular gland was necessarily the aetiological agent of the dacryoadenitis. This is of course true and theoretically one might obtain such a common inhabitant of the conjunctiva as the MoraxAxenfeld bacillus, from an apparently normal preauricular gland, were it practicable to obtain gland pulp. There is however a reasonable probability that the cause of the dacryoadenitis in one case of the three-and possibly in all three cases-was the bacillus of Morax-Axenfeld.

\title{
ANGIOGLIOSIS RETINAE WITH REPORT OF TWO CASES
}

\author{
BY \\ IDA CZUKRÁSZ, M.D. \\ (FROM THE UNIVERSITY EYE CLINIC, DEBRECEN, UNDER THE \\ CHARGE OF PROFESSOR A. KREIKER)
}

v. Hippel first described angiogliosis retinae which is a part of the group-complex tumours of ectodermal origin found in the parenchymatous organs. In a fourth of the cases reported with cystic angiomas of the brain, spinal cord, tonsils, kidneys, pancreas, 
ovaries, spleen, testicles, suprarenals and epidydimi glands, angiogliosis retinae was combined. Several cases have been reported establishing the recessive hereditary characteristic. Occasionally in members of the same family manifestations of this groupcomplex are evidenced by the presence of various parenchymatous tumours and angiogliosis retinae. Rochat's report suggests that this disease is transmitted through the female. It occurs most frequently in males.

The disease usually appears in childhood, but often adults present themselves to the ophthalmologist with loss of sight or pain.

Brand classifies four stages :-

(1) The alteration of the fundus vessels-they become tortuous and enlarged-at times combined with the appearance of solitary or multiple tumour-knots.

(2) The presence of haemorrhages and degenerative spots in the retina.

(3) Development of glaucoma, retinal detachment and other complications.

(4) The total destruction of the eye.

Radium treatment is advised by Sallmann, Moller and Ulrick when the diagnosis is made early. Good results have been published with this treatment.

In the later stages when glaucoma or detachment are present, enucleation is indicated to relieve pain or for cosmetic purposes.

Often the diagnosis is not made until after histological examination. 'The symptoms of glaucoma, the presence of retinal detachment, the tumour-shade from transillumination with the greenishyellow fundus reflex suggest the condition of glioma retinae.

The following two cases seem to be sufficiently rare to be recorded and were found among 100,000 patients of the University Eye-Clinic in Debrecen during the past 15 years. They belong to Brand's third classification, but we diagnosed them as glioma retinae and removed the eyes.

Upon sectioning the eye-balls we expected to find a heavy glial tumour, but were surprised to see a thin vermiform growth beneath the retina. We thought that we had found an as yet undescribed parasitic disease in the eye-ball. Though the neoplasm was larger than most of the published ones, we could not explain the pathological changes. Only later when the diagnosis of v. Hippel disease was made, were the cases clear.

The bulbs were fixed in formalin, horizontally sectioned, and 140 paraffin serial sections examined. 


\section{Case I}

A boy aged 8 years lost the sight of the right eye two months before entering the hospital. The patient had no complaints referable to any other disease. The family history was negative.

Clinical Notes.-There was no light perception in the right eye and the veins of the upper lid were tortuous. Between the superior and external recti muscles, $7 \mathrm{~mm}$. from the limbus a dark-blue area 6 by $8 \mathrm{~mm}$. was visible through the sclera. The corneal surface was hazy and stippled. Tension: +3 . The anterior chamber was very shallow. The pupil was of maximum width. A greenish-yellow fundus reflex was seen with focal light. There

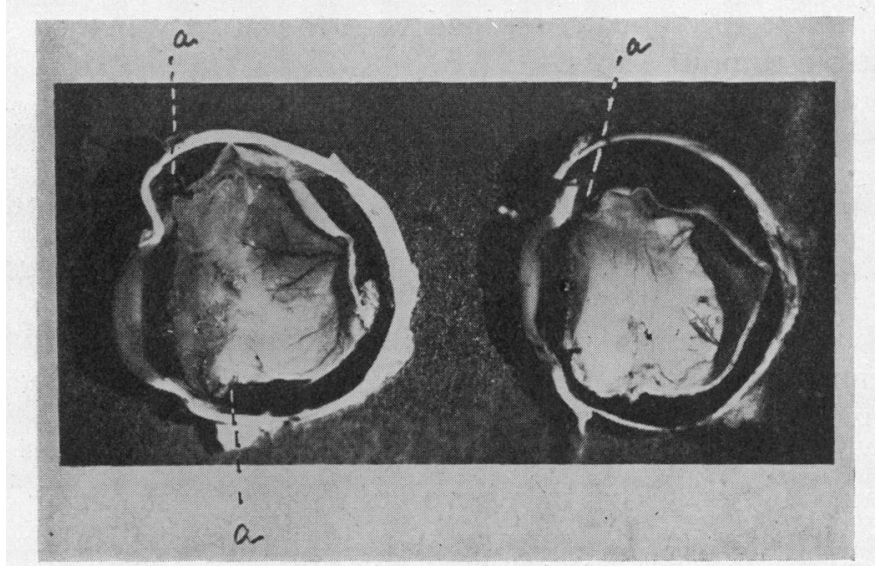

FIG. 1.

CASE I.-Photograph of the horizontally sectioned eye-ball.

(a) Showing the neoplasm behind the ora serrata.

was a retinal detachment of the lower hemisphere bulging 3 to $4 \mathrm{D}$. into the vitreous. There were many retinal haemorrhages, some of them 1 to 2 disc diameters. Ophthalmoscopically no tumour was seen, but the Lange lamp test was positive.

Pathological findings.-Immediately posterior to the ora serrata behind the retina and adherent to it was a yellowish string of tumour tissue $2 \mathrm{~mm}$. in diameter encircling the retina. There were numerous haemorrhages and yellow knots along the blood-vessels (Fig. 1).

We were astonished at the complete disorganisation of the retinal elements. The ganglion cells were destroyed. The nuclei of the inner nuclear layer and the cones and rods were partially necrotic. Glial tissue was abundant between the nerve and 


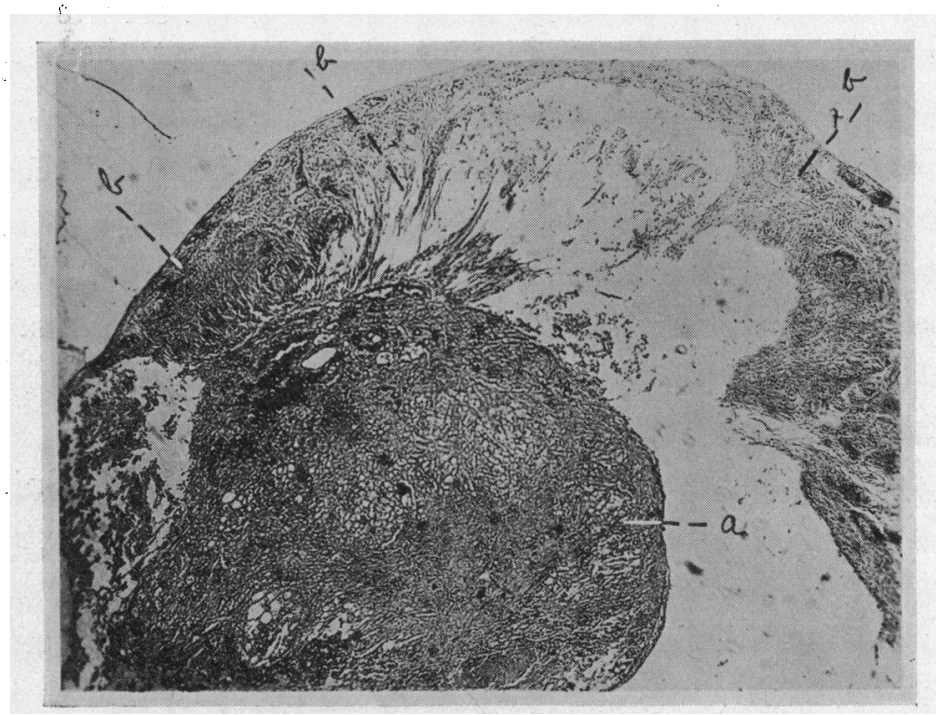

FIG. 2.

Microphotograph of the tumour. (a) Tumour with spaces of different sizes. Some of them showing blood-vessels, some cholesterin crystals. (b) Disorganized retina, with cystic degeneration

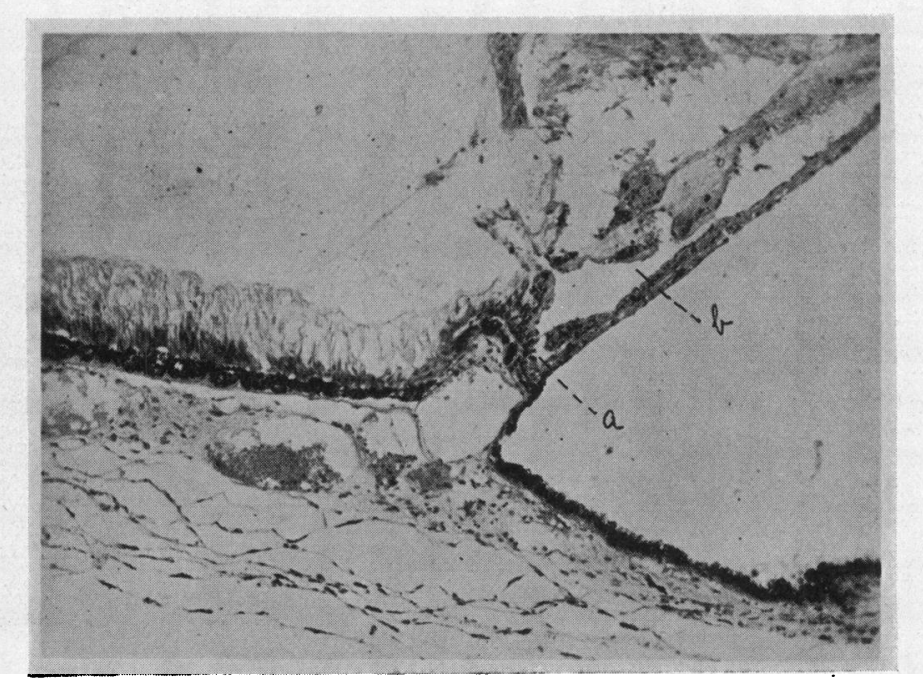

FIG. 3.

(a) Place where the retina divided into two layers. (b) Large blood-vessels between the two layers. 
Müller-fibres and among the remaining desolate neuroelements. The vessels were increased in number throughout the retina. They were enlarged and the perithelium thickened with hyaline degeneration. Amongst them glial-tissue, and pseudoxanthoma cells were present. In the latter we found fat, fuscin and cellular debris.

A tumour of $2 \mathrm{~mm}$. in width was lying posterior to the ora serrata behind and connected with the retina. It was composed of hyaline degenerated tissue, cholesterin crystals and vessels. In the neoplasm were irregularly shaped spaces of various sizes, lined by endrthelium and occasionally containing some blood. In some parts aneurysms were present (Fig. 2).

In some sections at the ora serrata the retina was indefinitely divided into two layers. We believed the former to be neuroepithelial structure and the latter to be of neuroelement. It was interesting to observe the tumour cells invading the two primary structures of the retina, and the choroid vessels. Some of the cells with well stained nuclei reminded us of embryonal neuroepithelium (Fig. 3).

\section{Case II}

Clinical Notes.-A boy of 11 years entered the hospital with pain and loss of vision in the left eye for six weeks. There was no light perception. The same marked glaucomatous signs were present as in Case 1. Retinal detachment was total. Several haemorrhages of different sizes and degenerative areas were present. Typical tumour findings were found with the diascleral light.

Pathological Findings.-A strange, reddish-grey, dychotomic, worm-shaped formation was seen in the upper part of the globe between the retina and the choroid (Fig. 4). This tumour was growing to the temporal edge of the optic disc and continued to the lower surface of the globe, and extended like a fan on to the adjoining retina. The structure of the retina was distorted here also. The nuclei of the first and third neurons were destroyed and only occasionally could we find a ganglion cell or cone and rod. Most pronounced was the disorganisation in the neuro-fibre layers as well as the layer of rods and cones. Vessels were increased in number and enlarged with a thick perithelium. The neural elements were replaced by neuroglial tissue and pseudoxanthorna cells. Mingled in the foamy-structure of these cells were considerable pigment granules (Fig. 5). Probably the conglomerations of fat in these cells created the ophthalmoscopic picture of the yellow degenerative spots. There were holes in the centre of these degenerations, representing the well-known cysticdegeneration of the retina. 


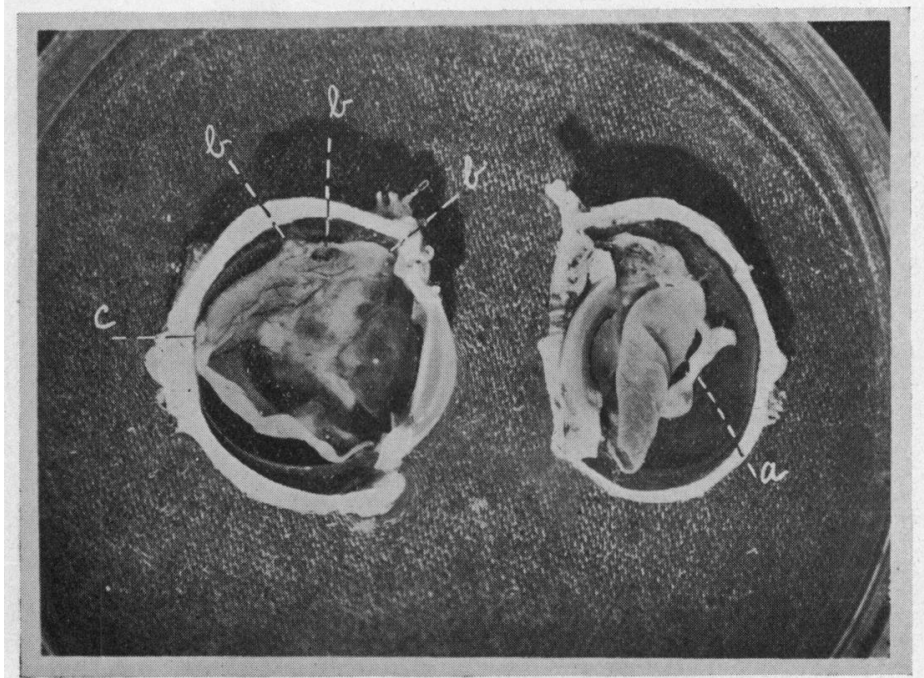

FIG. 4.

CASE II.-Horizontally sectioned eye-ball. (a) Dychotomic vermiform growth. (b) Tumour masses partly along the vessels, partly underneath the retina. (c) Invasion of neoplasm to the optic nerve sheath.

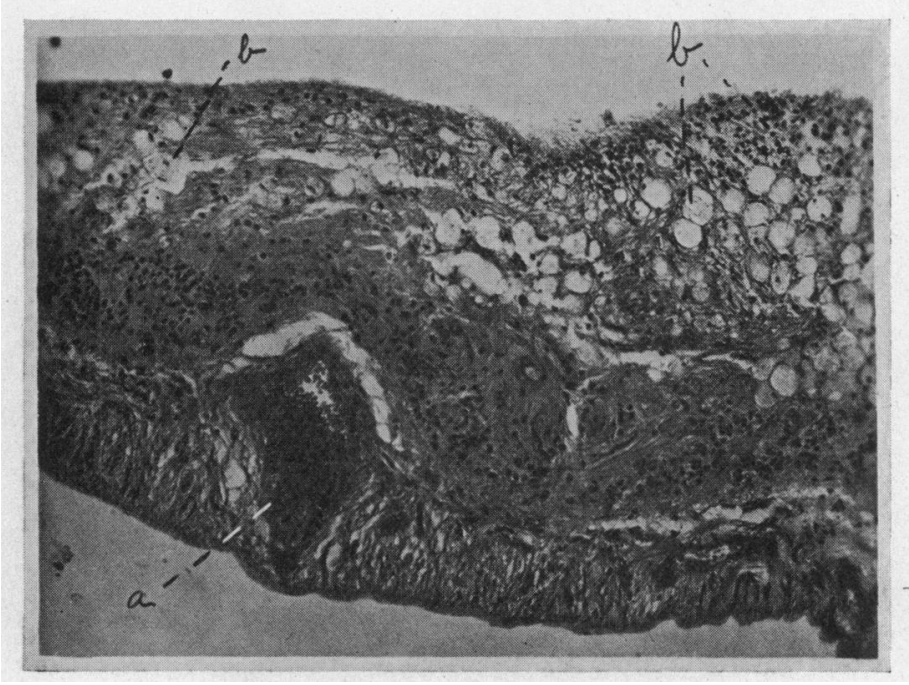

FIG. 5.

Microphotograph of the destroyed retina. (a) Enlarged vessel containing blood. (b) Pseudoxanthoma cells. 


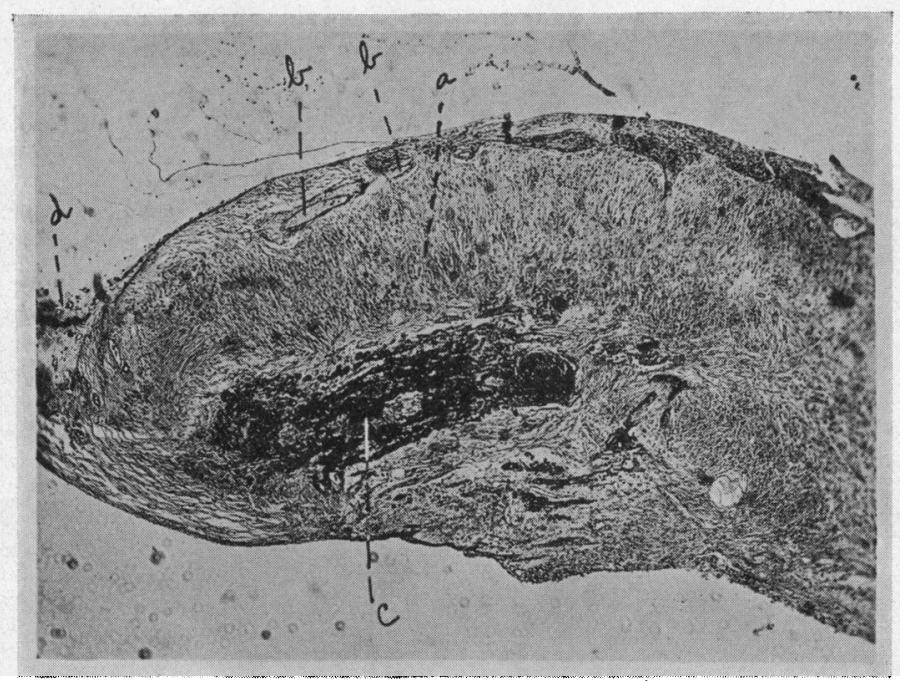

FIG. 6.

Neoplasm invading the retina. (a) Glial tissue. (b) Enlarged retinal vessels. (c) Group of isolated vessels surrounded with pigment cells. (d) Capillaries and embryonal neuroepithelial cells in the vitreous.

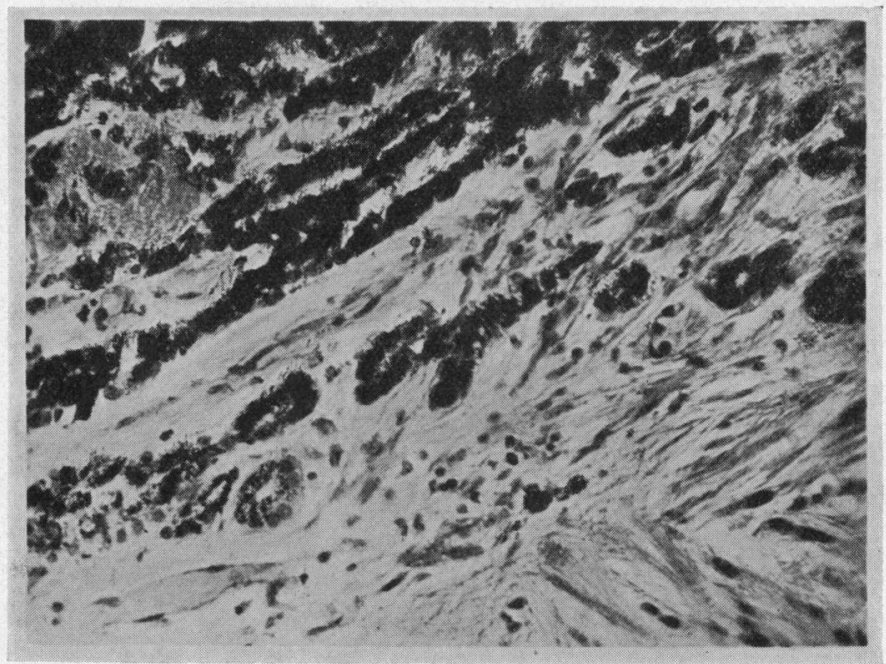

FIG. 7.

Pigment cells forming gland tubules. 
The retina thickened gradually from behind forward and at the ora serrata the neoplasm invaded it (Fig. 6). Neuroglial tissue was also present in the tumour tissue. In the middle of the tumour mass was a large group of isolated vessels, consisting mostly of capillaries, surrounded with pigment cells. The structure of these pigment cells appeared similar to the structure of pigment epithelium. The structure of these cells could be ascertained only in those cells containing a slight amount of pigment. In some areas these cells appeared like gland tubules (Fig. 7 ). These

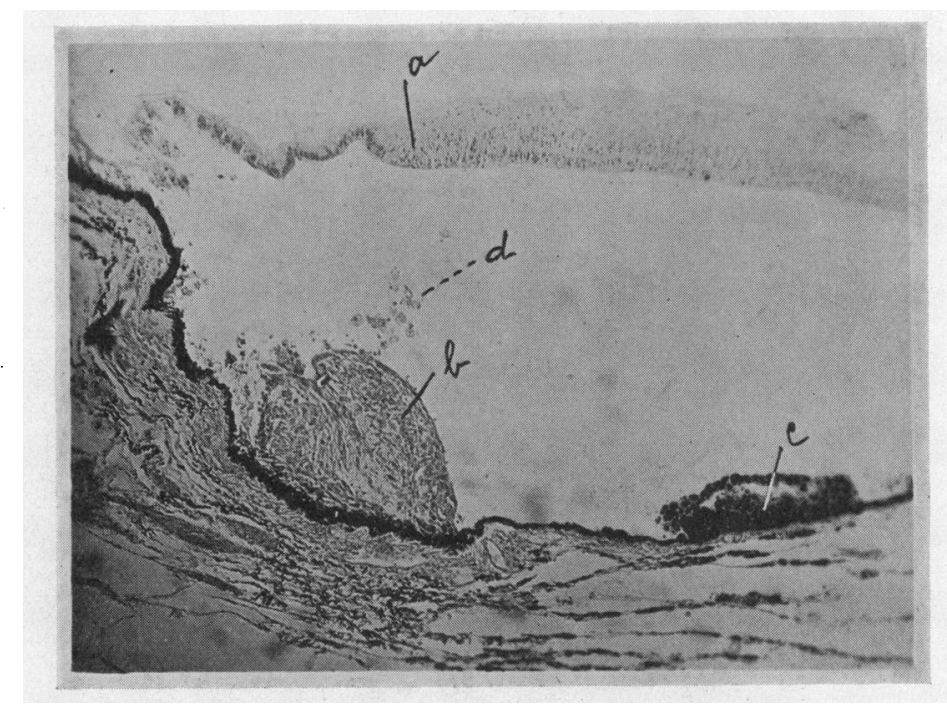

FIG. 8.

(a) Detached retina. (b) Tumour, directly connected with the pigment epithelium. (c) Pigment epithelium preforming neoplasm. (d) Phagocytes in the subretinal space.

formations and capillaries were present in the vitreous adjacent to the retina.

Cholesterin crystals and hyaline degeneration were seen in the growth that was lying free in the subretinal space.

The retina was detached up to the pars coeca plicata. The pigment epithelium layer was adherent to the choroid everywhere. Behind the pars plana coeca a branch of the tumour was directly connected with the pigment epithelium (Fig. 8). The cells of this area resembled the above described alveolar formations. A few millimetres behind this tumour was a tiny neoplasm of an entirely different structure. It consisted of 6 to 8 layers of honey-combed pigment cells. 
The dychotomic growth at the disc invaded the lamina cribrosa and extended to the optic nerve sheath (Fig. 9). It was not an infiltrative growth and probably proceeded outwards for more favourable growing conditions. All of the above described elements we could find in this part of the tumour except pigment cells.

Phagocytes, wandering-cells and pigment cells were abundant in the subretinal space. We are of the opinion that the profound glaucoma in this case, which we cannot explain from the size

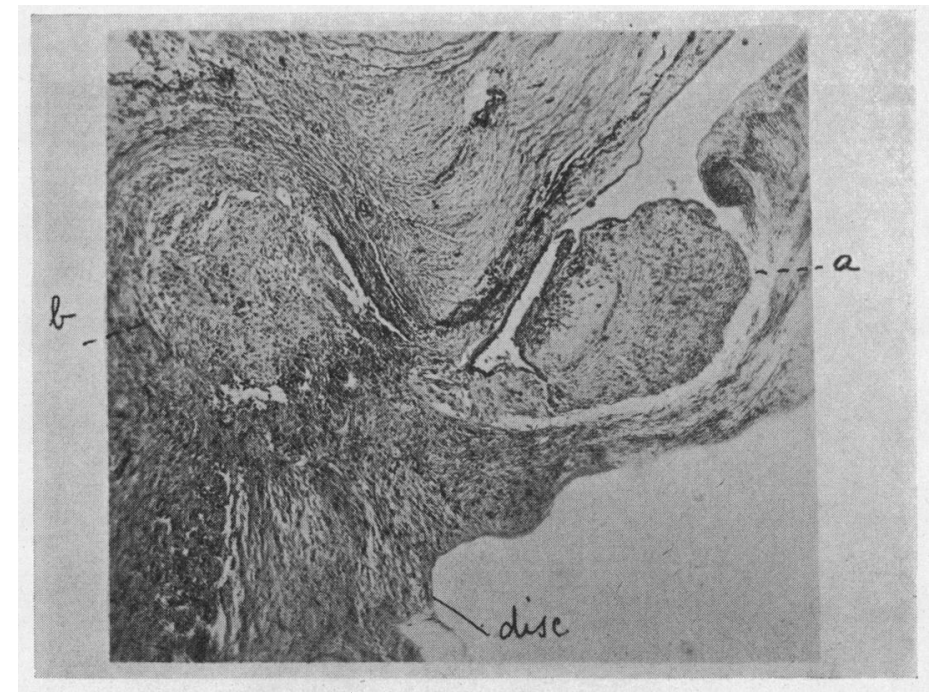

Fig. 9.

(a) Tumour between retina and choroid. (b) Neoplasm invasion of the optic nerve sheath.

of the tumour masses, was produced by a mechanical blockage of the angle of the anterior chamber by the wandering cells.

In these two cases we found a neoplasm, which combined with the glaucoma was responsible for the destruction of the retina. Though these tumours destroyed the function of the eyes and had expansive growth there was no evidence of infiltration nor metastases.

We feel that we can classify these tumours as hamartoma of the same type as the dysontogenetic tumours of the central nervous system.

Two opinions as to the origin of these tumours are found in the literature. Lindau, Möller, Rochat, Schuback, etc., claim that they have its origin primarily from blood-vessels (mesodermal). Meller and Marburg are of the opinion it is primarily a glial proliferation (ectodermal). 
We are convinced that these tumours are ectodermal in origin, but we want to point out that we believe the initiating cause lies in the neuroepithelium. Probably it begins from embryonal rests, growing and breaking the junctions of the neuroepithelial cells. Upon such a basis we might explain the presence of glial tissue, epithelial cells of embryological character, and pigmentepithelial growth. In our minds, the presence of blood-vessels in the tumour is only of secondary appearance.

We feel that these two cases are convincing evidence that angiogliosis retinae is different from other angiomatous tumours of the parenchymatous organs, but it belongs, as Lindau says, to the systematic parenchymatous malformations.

\section{LITERATURE}

Karasek.-Angiomatosis Retinae. Klin. Monatsbl.f. Augenheilk., Vol. XCV. Junius.-Zur Frage der Angiomatosis Retinae. Ergebnisse und Folgerungen. Klin. Monatsbl. f. Augenheilk., Vol. XCI.

Glinsberg, S., and Spiro, G.-Ueber Angiomatosis Retinae. Arch. f. Ophthal., Vol. LXXXVIII.

Berblinger.-Zur Auffassung von der sogenannten v. Hippelschen Kränkheit der Netzbaut. Arch. f. Ophthal., Vol. CX.

Dtrói.-Weitere Angaben zur Entwickelung der Angiomatosis Retinae. Klin. Monatsbl. f. A ugenheilk., Vol. LXXI.

Rochat.-Familiäre Angiomatosis Retinae und Kleinhirnangiom. Klin. Monatsbl. f. Augenheilk., Vol. LXXVIII.

Lindau.-Zur Frage der Angiomatosis Retinae und ihrer Hirnkomplikationen. Zentralbl. f. Ophthal., Vol. XIX.

Studien ueber Kleinhirncysten. Zentralbl. f. Ophthal., Vol. XVII.

v. Hippe1, E. - Noch einmal zur Angiomatosis Retinae. Arch. f. Ophthal., Vol. CXVIII.

Heine.-Ueber Angiogliosis Retinae und Hirntumor. Zeitschr. f. Augenheilk., Vol. LI.

Marchesani.-Anatomie der Angiomatosis Retinae und Retinitis exudativa. Arch. f. Ophthal., Vol. CIII.

Carr-Stallard.-A case of angiomatosis retinae. Brit. Jl. of Ophthal., Vol. XVII.

Niccol-Moore.-A case of angiomatosis retinae. Brit. Jl. of Ophthal., Vol XVIII. v. Hippel, E.-Angiomatosis Retinae und Retinitis exudativa (Coats). Arch. $f$. Ophthal., Vol. CXXVII.

\section{OPHTHALMIC TREPHINE SCISSORS*}

BY

\section{J. EDWARD MARTIN \\ CLIFTON}

I DESIGNED these scissors to facilitate the dissection of the flap before trephining, and I find them very comfortable in manipulation. The instrument has been made for me by Messrs. John Weiss and Son. The object of the design is to diminish flexion of the operator's wrist and thus avoid impairment of the finer movements of the hand.

\footnotetext{
* Reprinted from the Brit. Med. Jl., Vol. I, p. 223, 1937.
} 